\title{
Growth and Rumen Function of Gnotobiotic Lambs Fed on Starchy Diets
}

\author{
By P. N. HOBSON*, S. O. MANN AND C. S. STEWART \\ Rowett Research Institute, Bucksburn, Aberdeen AB2 9SB, U.K.
}

(Received 30 December 1980; revised 23 March 1981)

\begin{abstract}
Four gnotobiotic lambs were fed, after weaning, on a pelleted concentrate diet containing $90 \%$ barley. They were inoculated with a defined flora of 11 species of bacteria designed to reproduce the feed digestion of the conventional lamb. Cultural assessments of the growth of the bacteria and analysis of rumen fermentation products showed that rumen function was near normal, and the lambs grew steadily. However, at an age of about 115 to $130 \mathrm{~d}$, rumen function seemed to fail in three of the lambs and they rapidly lost weight and died. The fourth lamb was removed from isolation at about the same time, when there was some slight indication of loss of rumen function. Kept among conventional lambs it then continued to gain weight as did the conventional animals, but its rumen flora changed. The main species in the defined flora remained as major components of the rumen population after the lamb had been exposed to other animals, but in addition a mixed population of other bacteria, like that in conventional animals, quickly developed.

Other experiments showed that gnotobiotic lambs could be routinely weaned on to a concentrate feed containing $45 \%$ barley and $50 \%$ grass and that, when the lambs were inoculated with a defined flora similar to that given to the lambs in the first experiment, an adequate rumen fermentation could be established and the animals would grow. On changing to an all-grass feed, however, rumen function declined and the lambs ceased to grow. A change back to the barley/grass diet restored rumen fermentation and lamb growth, but whereas amylolytic bacteria were present in normal numbers, cellulolytic bacteria were absent and there appeared to be little, if any, fibre digestion. However, the rumen function again appeared to fail at about the same age of lamb as in the first experiment.
\end{abstract}

\section{INTRODUCTION}

Gnotobiotic (associated with a defined bacterial flora) and germ-free (with no known associated flora) small animals are now widely used in laboratory work, and larger animals have also been reared in these states. However, comparatively little work has been done with large ruminants, in spite of their importance to man and the number of experiments done with 'conventional' ruminants (born and reared under normal farm conditions and associated with a natural flora). There are two main reasons for this. First, the size of adult, or even young, cattle and sheep makes the necessary equipment large and the animals difficult to handle. Secondly, although many animals can live when germ-free, a ruminant can only be reared germ-free in its preruminant stage, on a milk feed. Its ability to live on solid food depends on the rumen, the development and function of which requires a microflora. Thus a gnotobiotic ruminant, while free from pathogenic and adventitious micro-organisms, must be provided with a known flora capable of developing the rumen as an organ and carrying on rumen digestive functions. The protozoa normally found in the rumen are not necessary for this. A study of gnotobiotic ruminants can thus lead to more understanding of the interactions and overall functions of the rumen microbes, and a ruminant growing normally with a defined 
rumen flora can be used to define interactions between commensal and pathogenic bacteria, the actions of feed components or additives, and so on.

Previous work by the authors and colleagues at Cambridge showed that, at least for a limited period, growth of two lambs with a defined rumen flora could be obtained when they were fed a mixed concentrate diet of a low-fibre type, which might be partially digestible by a non-ruminant. With these lambs, various aspects of the role of the rumen bacteria in the physical development of the rumen could be shown (Lysons et al., 1971, 1976, 1977; Leat et al., 1977). However, these experiments were pioneer ones in developing the methods for rearing the gnotobiotic animals, and times of inoculation of the rumen relative to age and feed were not standardized or near to normal. Later work has developed a more or less standardized system for rearing gnotobiotic lambs until after weaning on to a solid diet. This system is close to normal farm procedures as regards feeding, and similar to the natural inoculation with the rumen flora. But the continued rearing of older gnotobiotic lambs on grass has not yet been successful, and later work has not shown any reproducible or prolonged improvement over the experiments reported by Mann \& Stewart (1974).

Although the aim of good and reproducible growth of gnotobiotic lambs on a fibrous diet has not been attained, the younger lambs have proved valuable in a number of investigations (Sharpe et al., 1977; Barr et al., 1980; Cheng \& Wallace, 1979; Cushnie et al., 1979). More success has been obtained in rearing lambs and reproducing rumen function when starchy feeds have been used, and this paper reports results for lambs fed on an early-weaning diet and a commercial pelleted-barley diet used for feeding mature sheep.

\section{METHODS}

Diets. The composition of the two feeds is shown in Table 1. Diet A is a commercially used barley feed and diet B a starter feed generally used in rearing early-weaned lambs. The grass feed was a pelleted, coarsely ground dried grass (protein content about $17 \%$ ), with the same minerals/vitamin supplement as diets A and B. The mixed components were pelleted $(16 \times 16 \mathrm{~mm})$ and sterilized in suitably sized packages by $\gamma$-irradiation. The milk was a commercial canned evaporated cow's milk (Carnation Foods, London, U.K.), which is sterilized during preparation. Before giving to the lambs it was diluted 1:1 with sterile water. Water available to the older lambs was sterilized by autoclaving.

Apparatus. The isolators and cages, with methods for their sterilization and use, and methods for introduction and removal of food, excreta, samples and sampling equipment, etc., were mainly as already described (Alexander et al., 1973a,b), although some modifications have been introduced in the light of continued experience (Cushnie et al., 1981).

Feeding and sampling. Feedstuffs were introduced into the isolators in containers through an air lock with peracetic acid sterilization of all surfaces. Measured amounts of feeds were offered, the milk in one lot a day and the solids as one morning feed. The lambs were encouraged to drink the milk from a trough during their first day or two in the rearing isolators, and subsequently no difficulty was found in getting them to take milk. They were weaned by cutting down the milk (while offering the solid feed) over a period of a week and then given only solids. Residues were weighed back and each day's feed consumption was noted. Water was available ad lib but approximate consumption was noted. Rumen samples were taken by stomach tube into sterile bottles about $2 \mathrm{~h}$ after the morning feed. The lambs were weighed weekly at the same time of day by means of an external balance working through the isolator hood (Alexander et al., 1973a). The general condition and behaviour of the lambs were regularly noted. All times of inoculations and samplings are calculated taking the day of birth as day 0 .

Analyses. Rumen $\mathrm{pH}$ and volatile fatty acids (VFA) were determined by standard procedures already described (Mann \& Stewart, 1974).

Bacteria. The types of rumen bacteria used, the basic reasons for using these bacteria, and their origin, have been previously described, as have the media and methods used in re-isolation and counting the bacteria, and the procedures for inoculating the sheep (Lysons et al., 1976). Bacteroides amylophilus has limited fermentative activity and can grow only on a medium on which Bacteroides ruminicola can also grow. These bacteria were counted together as total colonies on the one medium, as was done previously (Lysons et al., 1976). Streptococcus bovis and Streptococcus faecium were also generally counted as total colonies, on Blood-Azide medium (Oxoid). The media used for counts of functional groups were based on the M8 agar medium used previously but with the 
Table 1. Composition of feeds for gnotobiotic lambs

\begin{tabular}{lclc} 
Component & $\%(\mathrm{w} / \mathrm{w})$ & & \multicolumn{2}{c}{ Component } \\
Barley & 90 & Grassmeal & Feed B \\
Whitefish meal & 10 & Whitefish meal & 50 \\
Supplement* & & $\begin{array}{l}\text { Dicalcium phosphate } \\
\text { Limestone }\end{array}$ & 4 \\
& Barley & 0.5 \\
& Supplement* & 45
\end{tabular}

* Each feed contained a minerals/vitamin supplement comprising (per t feed): vitamin A, 5000000 i.u.; vitamin D, $1000000 \mathrm{i}, \mathrm{u}$; ; vitamin E, 20000 i.u., $\mathrm{ZnSO}_{4} .7 \mathrm{H}_{2} \mathrm{O}, 150 \mathrm{~g}, \mathrm{MnSO}_{4} .4 \mathrm{H}_{2} \mathrm{O}, 80 \mathrm{~g}, \mathrm{MgO}, 200 \mathrm{~g}$; $\mathrm{CoSO}_{4} \cdot 7 \mathrm{H}_{2} \mathrm{O}, 5 \cdot 5 \mathrm{~g} ; \mathrm{Ca}\left(\mathrm{IO}_{3}\right)_{2} \cdot 6 \mathrm{H}_{2} \mathrm{O}, 1 \mathrm{~g}$.

lactate and carbohydrate energy sources replaced by pectin $(1 \%, \mathrm{w} / \mathrm{v})$, xylan $(1 \%)$ or soluble starch $(0.5 \%)$. Polysaccharide hydrolysis was determined by noting clearing around colonies in the xylan medium, clear zones in the pectin medium treated with Cetavlon (cetyltrimethylammonium bromide; ICI) to precipitate pectin, and loss of colour in starch medium treated with iodine. Proteolytic bacteria were counted by observation of zones of clearing on M8 agar basal medium without Casitone and yeast extract, and with maltose as the sole energy source, but with tryptose $(0.3 \%)$ and casein (1\%; prepared as by Blackburn \& Hobson, 1962) added. Lipolytic bacteria were counted on the M8 base without lactate or sugars but with $0.5 \%$ linseed oil emulsion prepared by ultrasonic dispersion (Henderson, 1973). A medium containing filter-paper strips (Mann, 1968) was used to determine whether cellulolytic activity was present in the samples. Routine tests for contaminant bacteria in the isolators and the lambs were made before the inoculations, and subsequently, by procedures similar to those of Elliot et al. (1974), and cultures for re-isolation of the defined flora were examined for contaminants in the rumen. Glucose was also added to the dilutions of rumen contents used for counts and these were then incubated anaerobically for $72 \mathrm{~h}$ and used to inoculate blood-agar plates which were incubated aerobically and anaerobically for 48 and $72 \mathrm{~h}$, respectively, before examination for contaminants. Dilutions were also plated on Sabouraud agar (Oxoid) to test for fungal contaminants.

Animals. The lambs were derived by hysterectomy, revived and given their first milk in a transfer isolator; after a few hours they were introduced to the rearing isolator and cage by techniques very similar to those already described (Alexander et al., 1973 b). Ewes bearing twin (or occasionally triplet) lambs were used and hysterectomy was performed a day from full term. In the experiments on barley feeding (diet A) four Suffolk $x$ Finn Dorset lambs (designated L. M, N and O) were obtained as two pairs of twins within weeks of each other and were reared in individual isolators. The isolators were contained in separate, adjacent small rooms with doors on to a common corridor. The lambs on the early-weaning diet (B) were reared for different experiments and not necessarily at the same time. They were of the same breed.

Feeding and inoculation of lambs fed on barley. The lambs were fed increasing amounts of milk for $21 \mathrm{~d}$ and then weaned on to the barley pellets (feed A, Table 1) over the next $7 \mathrm{~d}$. The same rumen bacteria were inoculated into each at the same ages. Lactobacillus casei (Lactobacillus LB 17 of Sharpe et al., 1977), Streptococcus bovis and Megasphaera elsdenii were given at $22 \mathrm{~d}$, with the first barley, and Veillonella alcalescens at $25 \mathrm{~d}$. These were followed by Selenomonas ruminantium, Bacteroides ruminicola and Bacteroides amylophilus on days 33, 34 and 35, by Butyrivibrio fibrisolvens on day 40, by Anaerovibrio lipolytica and four strains of Ruminococcus spp. (all actively cellulolytic in vitro) on days 42 and 43, and by the ureolytic Streptococcus faecium on day 47.

Feeding and inoculation of lambs fed on starchy concentrates. The feed of starchy concentrates (feed B, Table 1) was routinely used as a post-weaning diet for all gnotobiotic lambs that were to be eventually fed on grass (e.g. Mann \& Stewart, 1974). Lambs were weaned as above, the concentrates being offered while milk supply was being reduced. When weaning was complete, feed B was given for about 3 weeks before the diet was changed to grass pellets. In some cases the diet was changed from grass back to concentrates, as described in Results. The defined floras were given by the end of weaning. At $6 \mathrm{~d}$ and $34 \mathrm{~d}$, lambs $\mathrm{T}$ and $\mathrm{U}$ were given two complete inoculations of the same flora as lambs $\mathrm{L}, \mathrm{M}, \mathrm{N}$ and $\mathrm{O}$, but with only two strains of Ruminococcus and in addition Methanobacterium ruminantium. A strain of Escherichia coli was also given. Previous experiments had shown that in the presence of lactobacilli or a complete defined rumen flora the $E$. coli did not affect the health of the lambs. Small numbers of $E$. coli, as well as other bacteria generally regarded as non-essential to rumen function, are regularly found in the conventional rumen and a question posed by the gnotobiotic lamb work was whether these bacteria could have some effect on the feed digesting bacteria. 


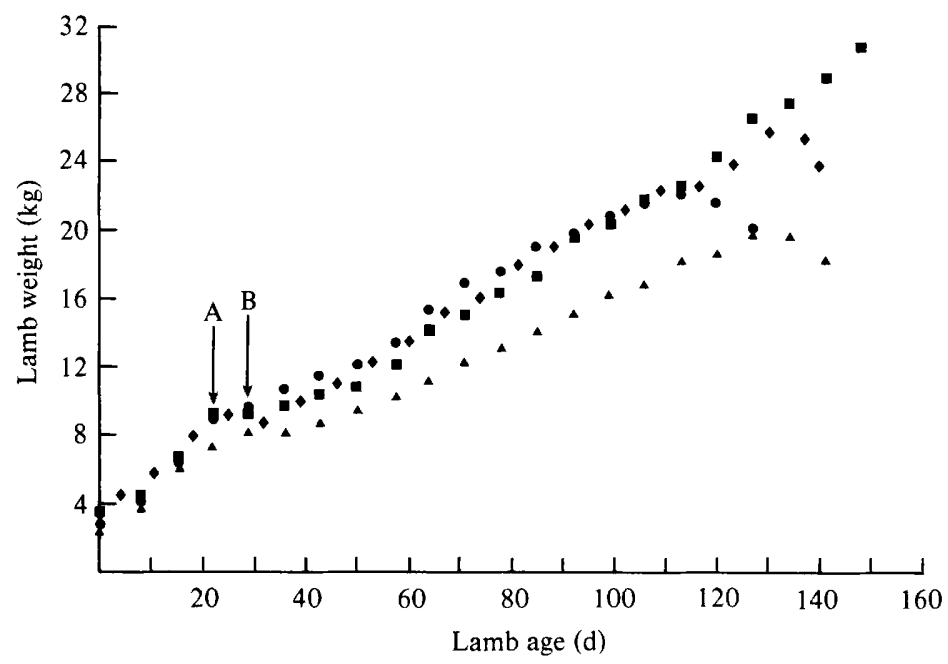

Fig. 1. Weight gains of lambs L (O), M (A), N ( $\square)$ and $\mathrm{O}(\bullet)$ while in isolators. Milk alone was fed until $A$; between $A$ and $B$ the lambs were weaned on to pelleted barley.

Table 2. Numbers of rumen bacteria in lambs fed on barley pellets

All the counts are expressed as $\log _{10}$ [number (g rumen contents) $\left.{ }^{-1}\right]$. A count under two headings means that both bacteria were determined on the same medium. Anaerovibrio lipolytica was counted only once: in lamb $\mathrm{M}$ on day 77 the count was 7.76 .

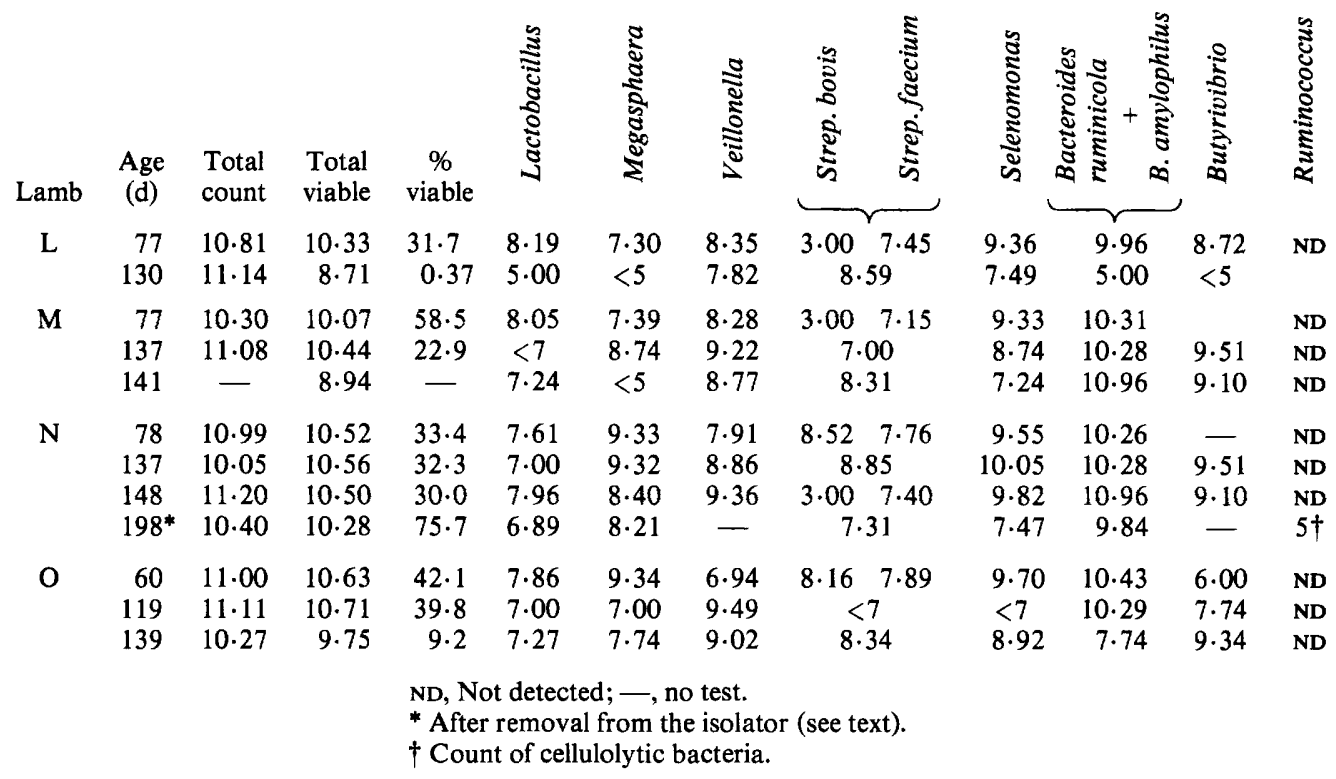

\section{RESULTS}

\section{Lambs fed on pelleted barley}

Since the flora inoculated had been used for other gnotobiotic lambs and it was known that the bacteria would establish, in the earlier part of the experiment only microscopic examination of rumen samples was used to check that a mixed flora was present. Results of later cultural tests are shown in Table 2, and analyses of rumen acids in Table 3 . The growth 
Table 3. Analyses of rumen contents of lambs fed on barley pellets

\begin{tabular}{|c|c|c|c|c|c|c|c|c|}
\hline \multirow[b]{2}{*}{ Lamb } & \multirow{2}{*}{$\begin{array}{l}\text { Age } \\
\text { (d) }\end{array}$} & \multirow{2}{*}{$\begin{array}{c}\text { Rumen } \\
\text { pH }\end{array}$} & \multicolumn{6}{|c|}{ Organic acid conen $\left[\mu \mathrm{mol}(\mathrm{ml} \text { rumen fluid })^{-1}\right]$} \\
\hline & & & Acetic & Propionic & Butyric & Valeric & Total VFA & Lactic \\
\hline $\mathrm{L}$ & $\begin{array}{r}68 \\
77 \\
89 \\
130\end{array}$ & $\begin{array}{l}5 \cdot 0 \\
6 \cdot 2 \\
5 \cdot 9 \\
7.0\end{array}$ & $\begin{array}{l}49 \\
32 \\
35 \\
19\end{array}$ & $\begin{array}{r}34 \\
20 \\
33 \\
5\end{array}$ & $\begin{array}{r}12 \\
6 \\
8 \\
1\end{array}$ & $\begin{array}{r}15 \\
9 \\
9 \\
\text { ND }\end{array}$ & $\begin{array}{r}110 \\
67 \\
85 \\
25\end{array}$ & $\begin{array}{l}2 \\
1 \\
2 \\
1\end{array}$ \\
\hline $\mathbf{M}$ & $\begin{array}{r}68 \\
77 \\
89 \\
130 \\
137 \\
141\end{array}$ & $\begin{array}{l}5 \cdot 8 \\
5 \cdot 6 \\
6 \cdot 2 \\
6 \cdot 0 \\
6 \cdot 5 \\
7 \cdot 0\end{array}$ & $\begin{array}{l}48 \\
37 \\
29 \\
34 \\
27 \\
24\end{array}$ & $\begin{array}{r}24 \\
28 \\
24 \\
28 \\
22 \\
8\end{array}$ & $\begin{array}{l}8 \\
7 \\
5 \\
8 \\
6 \\
2\end{array}$ & $\begin{array}{l}6 \\
7 \\
6 \\
9 \\
8 \\
1\end{array}$ & $\begin{array}{l}86 \\
79 \\
64 \\
79 \\
63 \\
35\end{array}$ & $\begin{array}{l}2 \\
1 \\
1 \\
1 \\
2 \\
2\end{array}$ \\
\hline $\mathrm{N}$ & $\begin{array}{r}68 \\
78 \\
89 \\
137 \\
148 \\
198\end{array}$ & $\begin{array}{l}6.4 \\
5.4 \\
5 \cdot 3 \\
5 \cdot 5 \\
6 \cdot 5 \\
5 \cdot 7\end{array}$ & $\begin{array}{l}45 \\
28 \\
22 \\
44 \\
26 \\
32\end{array}$ & $\begin{array}{l}38 \\
21 \\
30 \\
47 \\
27 \\
33\end{array}$ & $\begin{array}{l}7 \\
4 \\
5 \\
4 \\
3 \\
5\end{array}$ & $\begin{array}{r}6 \\
9 \\
10 \\
9 \\
6 \\
\text { ND }\end{array}$ & $\begin{array}{r}96 \\
62 \\
67 \\
104 \\
62 \\
70\end{array}$ & $\begin{array}{c}2 \\
1 \\
2 \\
2 \\
1 \\
\text { ND }\end{array}$ \\
\hline $\mathrm{O}$ & $\begin{array}{r}50 \\
60 \\
71 \\
119 \\
139\end{array}$ & $\begin{array}{l}5 \cdot 4 \\
5 \cdot 1 \\
5 \cdot 1 \\
5 \cdot 9 \\
6 \cdot 8\end{array}$ & $\begin{array}{l}31 \\
62 \\
38 \\
39 \\
41\end{array}$ & $\begin{array}{l}16 \\
51 \\
44 \\
33 \\
31\end{array}$ & $\begin{array}{r}10 \\
8 \\
7 \\
9 \\
\text { ND }\end{array}$ & $\begin{array}{l}13 \\
15 \\
17 \\
10 \\
\text { ND }\end{array}$ & $\begin{array}{r}70 \\
136 \\
106 \\
91 \\
72\end{array}$ & $\begin{array}{r}3 \\
2 \\
2 \\
2 \\
\end{array}$ \\
\hline
\end{tabular}

ND, Not detected; - , no test.

of the lambs is shown in Fig. 1. Blood glucose levels were all within the normal ranges, being on average $70-75 \mathrm{mg}$ per $100 \mathrm{ml}$ during the last $50 \mathrm{~d}$ or so of the experiments and higher when the lambs were younger (seven or eight tests on each lamb).

A Gram-positive, sporing rod contaminant was noted in the faeces of lamb $\mathbf{N}$ at about $26 \mathrm{~d}$, but this was not found later. Some Gram-positive and Gram-negative sporing rods were seen in the rumen samples from lamb $\mathrm{O}$ at $119 \mathrm{~d}$, and a Bacillus $\mathrm{sp}$. and Clostridium welchii were cultured in numbers of about $10^{4}$ and $10^{7}$ (g rumen contents) ${ }^{-1}$, respectively, in the $139 \mathrm{~d}$ sample. No other contaminants were detected.

The bacterial counts show that all the inoculated bacteria established, with the exception of the cellulolytic ruminococci. Because of its small colony size on lipid agar, A. lipolytica, although detected at other times, was counted only once. The total count was similar (in the earlier tests) to that found in conventional lambs. The percentage of viable rumen bacteria in samples from conventional animals fed on barley has been found to be higher than that in animals fed on fibrous diets (Eadie et al., 1970). The percentage of viable bacteria in these lambs was high, although not quite as high as the values reported for conventional lambs (about $70 \%$ ) or as high as in lamb $\mathrm{N}$ when moved to pens beside conventional lambs ('conventionalized'; see below).

It can be seen from Fig. 1 that after a slight (and normal) growth check on weaning, the lambs steadily gained weight. Lamb $\mathbf{M}$, with the lowest birth weight, did not do quite as well as the others. Feed intake increased during barley feeding, and lamb $\mathrm{N}$ was eating from $900 \mathrm{~g}$ to over $1000 \mathrm{~g}$ barley a day during the last 2 or 3 weeks it was in the isolator. Over the whole period of barley feeding the feed conversion efficiency of lamb $\mathrm{N}$ ( $\mathrm{kg}$ food eaten per $\mathrm{kg} \mathrm{wt}$ gain) averaged 3.8. Over the 7 weeks after conventionalization it ate more but it was approaching its maximum weight and its food conversion efficiency was $4 \cdot 8$.

At about 115 or $130 \mathrm{~d}$, lambs L, M and O lost appetite and ceased to gain weight (Fig. 1). At the same time the viable count and percentage of viable bacteria fell, as did the rumen 
VFA concentration (Tables 2, 3). Lamb L died in the isolator on day 131. Lambs $M$ and $O$ were moved to pens beside conventional lambs on days 141 and 140, but died on days 143 and 145, respectively. Lamb $\mathrm{N}$ continued to gain weight. The rumen VFA content was lower at $148 \mathrm{~d}$ than in the previous sample (Table 3), but bacterial counts and percentage viable bacteria were as before. Lamb $\mathrm{N}$ was moved to pens beside conventional sheep after sampling on day 148 and continued to thrive. It weighed $30.9 \mathrm{~kg}$ on removal from the isolator and increased in weight over the next week to $32.5 \mathrm{~kg}$. Feed intake gradually increased from 1 to $1.9-2.0 \mathrm{~kg} \mathrm{~d}^{-1}$ in the $55 \mathrm{~d}$ after removal from the isolator, and the lamb's weight increased steadily to $47.4 \mathrm{~kg}$. Rumen samples were analysed towards the end of this period, when the lamb was about $198 \mathrm{~d}$ old, with the results shown in Tables 2 and 3. Methanogenic bacteria were cultured soon after removal of the lamb, but were only counted in detail after the lamb had been changed to a grass feed at $200 \mathrm{~d}$ old. The lamb continued to thrive after the change to grass cubes and it reached a weight of $51 \mathrm{~kg}$ about $36 \mathrm{~d}$ after the change and was finally killed at a weight of $59.2 \mathrm{~kg}$. The only sign of adverse reaction to the exposure to conventional lambs in an unheated sheep house in February was a slight scouring a few days after the change in housing.

\section{Lambs fed on barley/grass concentrates or all-grass pellets}

Diet B has been used as a post-weaning feed for all gnotobiotic lambs which were to be eventually fed on grass (e.g. Mann \& Stewart, 1974). The barley grain would be damaged by pelleting, thereby exposing the starch to bacterial digestion, but it was hoped that the quantity eaten, because of the admixture with grass and other components, would not be sufficient to cause the rumen $\mathrm{pH}$ to fall excessively. The presence of the grass should then have encouraged growth of a cellulolytic flora and so facilitated the change to an all-grass diet.

All lambs showed some check on weaning, as is normal, but after 3 weeks on diet B all were gaining weight and a rumen fermentation was taking place. In tests on eight lambs during this post-weaning period the average total rumen VFA content was $57 \cdot 1 \mu \mathrm{mol} \mathrm{ml} \mathbf{l}^{-1}$, made up of $\left(\mu \mathrm{mol} \mathrm{ml}^{-1}\right): 25.8$ acetic, 19.4 propionic, 9.6 butyric, and 2.3 valeric acid. Lactic acid averaged $1.1 \mu \mathrm{mol} \mathrm{ml}{ }^{-1}$; rumen $\mathrm{pH}$ was about 6.9 .

When lambs were changed to a grass-pellet feed, growth continued, but it was slight and erratic and after various periods (a few weeks) it entirely ceased. At this point the lambs could be saved by giving them a conventional rumen flora by inoculation or by exposure to other animals. However, short-term experiments suggested that the defined rumen flora could still digest diet B, and if the lambs were changed quickly to this feed when growth on grass had ceased they could recover and grow. The digestion of diet B in older lambs was followed in more detail and for a longer period in two lambs, designated $T$ and $U$. These lambs were gaining weight on diet $\mathrm{B}$ and so grass cubes were substituted from day 51 . The change was followed by a drop in weight. Microscopic observations showed a mixed flora, but to try to ensure that all bacteria had established, another inoculation of the complete flora was given on day 63 . However, by day 70 lamb T had lost $1.8 \mathrm{~kg}$ and lamb U $1.4 \mathrm{~kg}$. They were then changed back to diet $\mathrm{B}$ and immediately began to gain weight, and continued to do so until day 138. In this period the weight of lamb $T$ increased from 8.6 to $16.5 \mathrm{~kg}$ and that of lamb $\mathrm{U}$ from 9.8 to $20.6 \mathrm{~kg}$ (weight gains of 0.12 and $0.16 \mathrm{~kg} \mathrm{~d}^{-1}$ ). Daily feed intake averaged $600 \mathrm{~g}$ for lamb $\mathrm{T}$ and $850 \mathrm{~g}$ for lamb $\mathrm{U}$. The results of some tests on rumen function are shown in Table 4. Weight gains were constant, although not as high as on the barley feed, and rumination was normal and the lambs were active. As the lambs were growing well it was decided to change them to the barley feed (A) for another experiment. One lamb was changed at $138 \mathrm{~d}$ and the other at $141 \mathrm{~d}$. The lambs were still gaining when weighed at $138 \mathrm{~d}$, but between then and the next weighing at $141 \mathrm{~d}$ they both lost about $0.3 \mathrm{~kg}$. Feed intake became irregular about this time and became generally lower, falling by $50-100 \mathrm{~g} \mathrm{~d}^{-1}$. The lambs never recovered their former weight gains and were killed at $154 \mathrm{~d}$ old, when post-mortem 


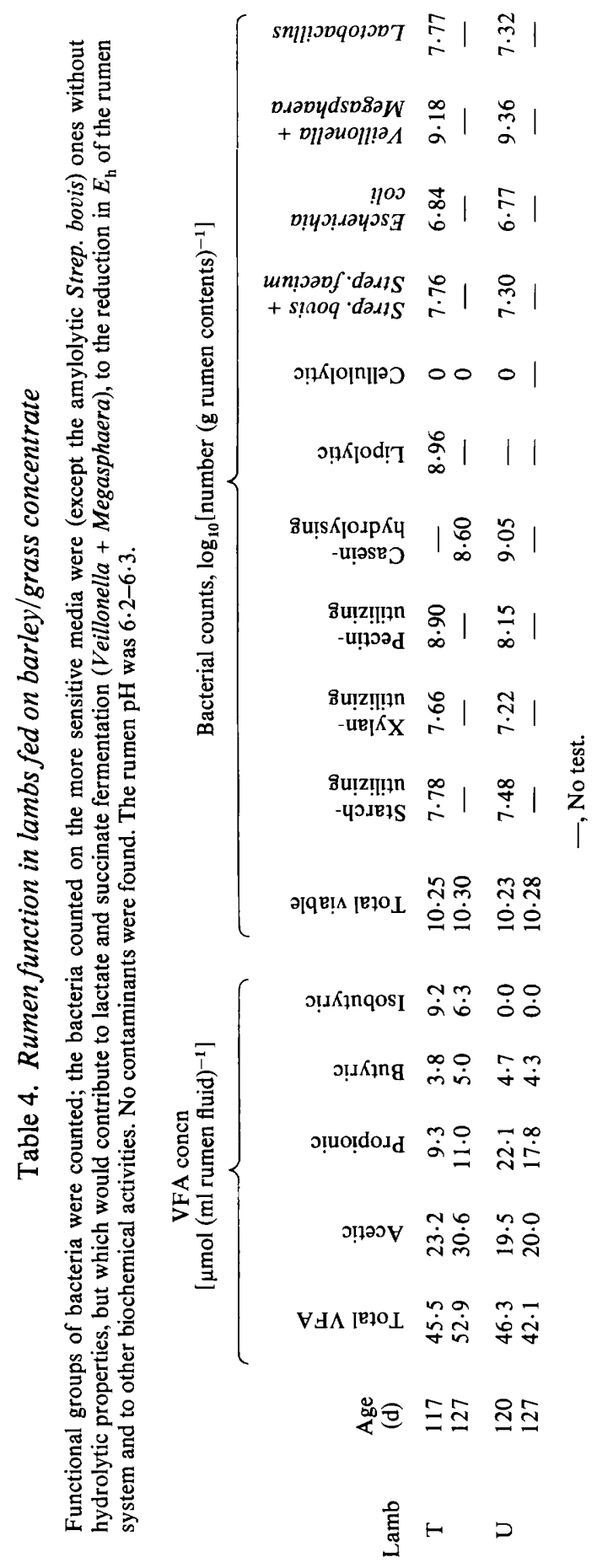


examination again showed no pathological lesions, only a general appearance of under-nutrition.

\section{DISCUSSION}

The feeds used in all these experiments were ones used in commercial lamb feeding and were all nutritionally adequate for conventional lambs of ages comparable with the gnotobiotic lambs.

\section{Lambs fed on pelleted barley}

The reasons for not attempting to establish ciliate protozoa in the rumen populations of gnotobiotic lambs have been given previously (Lysons et al., 1976). However, ciliate protozoa are not found in conventional lambs fed ad lib on pelleted barley (Eadie et al., 1970), so their absence here would not affect the rumen function.

The absence of ruminococci might be expected in lambs on pelleted barley, as the pelleting process cracks the grains, exposing the starch to bacterial attack. Extensive starch fermentation produces a generally low rumen $\mathrm{pH}$, and the $\mathrm{pH}$ values reported here (Table 3 ) are typical of conventional lambs fed on pelleted barley; in such lambs cellulolytic bacteria are in very low numbers or undetectable (Mann \& Ørskov, 1975). Bacteroides species are the predominant bacteria in the rumen populations of conventional barley-fed animals (Eadie et al., 1970), and the starch-fermenting Bacteroides, with Selenomonas and Strep. bovis, were the principal components of the floras in the gnotobiotic lambs.

The lack of bacteria able to attack cellulose (the ruminococci) suggests that the rumen acids came principally from the fermentation of starch. The properties of the predominant bacteria defined by in vitro experiments support this suggestion. Bacteria-free solutions of the a-amylase of Strep. bovis (Hobson \& MacPherson, 1952) attacked starch granules in the mass slowly, but attack was shown to originate in microscopically visible or submicroscopic cracks in the granules (Baker \& Hobson, 1952) and damage to the granules increased the rate of degradation. Tests showed that Strep. bovis adhered to starch granules, thus producing high enzyme concentrations near the granules, and Hamlin \& Hungate (1956) later showed that B. amylophilus also adhered to and degraded starch granules. Both Strep. bovis and $B$. amylophilus will grow at lower $\mathrm{pH}$ values than the ruminococci and the $\alpha$-amylase of Strep. bovis had near-maximum activity from $\mathrm{pH} 5$ to 7 while $B$. amylophilus $\alpha$-amylase had optimum activity at $\mathrm{pH} 6.3$, with about $70 \%$ of this activity at $\mathrm{pH} 5.5$ (Hobson \& MacPherson, 1952; McWethy \& Hartman, 1977). Amylase production by B. amylophilus was maximal at $\mathrm{pH} 6$, with about $80 \%$ of this activity at $\mathrm{pH} 5.5$ at a constant growth rate, but specific activity (per unit cell wt) increased rapidly at low growth rates under $\mathrm{N}$ or $\mathrm{C}$ limitation at constant $\mathrm{pH}$ (Henderson et al., 1969). This means that even if the bacteria in the gnotobiotic rumens had a lower growth rate than in the conventional sheep, this need not necessarily have led to amylase activity being a factor limiting fermentation. Feed intake and rates of feed digestion and passage are related, and the rather less than optimal intake of the gnotobiotic lambs suggests that ruminal turnover rates were less than those in the conventional animal.

The total VFA concentrations in the earlier tests were similar to those in conventional lambs fed on pelleted barley, and the ratio of acetic to propionic acids was similar to values found by Ørskov et al. (1974) for such lambs. In the gnotobiotic lambs, a high proportion of propionic acid might be expected from the preponderance of propionic acid-producing and succinic acid-producing bacteria (bacteroides and selenomonads). Succinic acid would be converted to propionic acid by the Veillonella and possibly by the Selenomonas. Scheifinger \& Wolin (1973) reported that a strain of Selenomonas converted succinic acid to propionic acid in vitro, but an earlier experiment with a gnotobiotic lamb containing the strain of Selenomonas used in the present study showed no evidence for this activity in vivo (Mann \& 
Stewart, 1974). However, although the preponderance of these bacteria would increase the amount of propionic acid formed by normal fermentation pathways, a further mechanism would probably come into action. The rumen floras contained no methanogenic bacteria, which normally act as a sink for hydrogen produced in the rumen fermentations and which, by abstraction of hydrogen, bias the fermentation towards production of acetic acid and not the more reduced acids (e.g. Latham \& Wolin, 1977). Hydrogen produced by fermentation in the gnotobiotic lambs would then be available to the propionic acid- or succinic acid-producing bacteria, some of which (B. ruminicola, $S$. ruminantium and $A$. lipolytica were tested) have been shown to take up hydrogen in vitro, with the formation of more reduced acids and less acetic acid than is found in the absence of hydrogen (Henderson, 1980). Fermentation balances suggest that the proportion of substrate hydrogen not found in fermentation products was small, and other reactions, e.g. reduction of sulphate and the hydrogenation of unsaturated dietary fatty acids, which has been shown to occur in lambs with this defined rumen flora (Leat et al., 1977), might utilize much of this remaining reducing power.

The butyrivibrios and lactic acid bacteria were relatively minor components of the flora. This would account for the low concentrations of butyric and lactic acid, although the latter could be fermented by the Veillonella and Megasphaera. Valeric acid would be formed by the Megasphaera, and some might come from deaminative reactions of $B$. ruminicola.

The VFA are precursors of glucose or fats as a source of energy for ruminants, and the blood glucose levels found here are within the normal range for lambs.

There was a slight check in weight gain (as is normal) at weaning (Fig. 1). After weaning, the lambs made steady progress, although the one with the lowest birth weight did not do as well as the rest. The weight gains and feed conversion efficiencies compared well with those of conventional lambs on a starchy-concentrate diet used in previous gnotobiotic lamb experiments, where efficiencies of 3.4 to 3.8 were found over 5 week periods in lambs about 70 to $119 \mathrm{~d}$ old (Lysons et al., 1977). However, the weight gains and efficiencies were below those of conventional Cheviot $\times$ Suffolk lambs fed on the same type of pelleted barley feed in another experiment (Ørskov et al., 1973). The Cheviot $\times$ Suffolk lambs are a bigger breed than the gnotobiotic lambs and might be expected to gain more weight. In the experiment of Ørskov et al. (1973) the female lambs did not gain weight as well as the males, but in the gnotobiotic group in the present study there was no difference between females $(\mathrm{L}, \mathrm{O})$ and males $(\mathbf{M}, \mathbf{N})$.

Ruminal nitrogen metabolism in the gnotobiotic lambs was not examined, but proteolytic, deaminative and ureolytic activity should have been provided by $B$. amylophilus, $S$. ruminantium, B. ruminicola and Strep. faecium (Lysons et al., 1976). Dietary protein not completely degraded in the rumen would become available to the lamb after digestion in the abomasum and small intestine, and indeed, provision of some protein which escapes rumen degradation and is digested in the intestines is desirable in conventional growing lambs (Ørskov, 1977). On the other hand, little starch undegraded in the rumen can be utilized by ruminants (Ørskov et al., 1969).

Although the lambs grew well, if not perhaps quite at maximum potential, lambs L, M and $\mathrm{O}$ failed suddenly at similar ages, and the suggestion is made that the rumen flora failed to function. It is, of course, difficult to say whether lamb $\mathrm{N}$ would similarly have failed if left longer in the isolator, but the fact that it continued to gain weight after removal showed that no physiological lesion had developed during the gnotobiotic period to impair feed utilization. Post mortem examination of lambs $L, M$ and $O$ showed no cause of death other than starvation. The lambs had little fat and appeared undernourished to various extents. Presumably if rumen function was suboptimal the growing lambs would be unable to build up bodily reserves and would deteriorate rapidly if rumen function failed. Comparison of the rumen flora and VFA before and after conventionalization suggests that the defined flora was of the right type for digestion of this feed. In lamb $\mathrm{N}$, the principal species of the defined flora 
were still present, in numbers similar to when the lamb was in isolation, some weeks after its removal to the sheep house. The main difference between lamb $\mathrm{N}$ in the gnotobiotic and the conventionalized condition was that the percentage of viable bacteria was higher after conventionalization, and that in addition to the bacteria noted in Table 2 there was both a total streptococcal viable count of $4.6 \times 10^{8} \mathrm{ml}^{-1}$ and also a very varied flora of Gram-positive and Gram-negative rods and cocci (counted as morphological types), generally in numbers a factor of 10 to 1000 less than the bacteroides and selenomonads. There were also small numbers, (about $10^{3} \mathrm{ml}^{-1}$ ) of $E$. coli. In fact, the flora had reverted to a normal rumen mixture, and although the defined flora consisted of high numbers of bacteria it did not exclude development of 'foreign' bacteria.

The counts do not show whether the bacteria isolated later were the same strains as those in the defined flora. It is a common finding in mixed-microbial habitats such as the rumen that a large number of slightly different strains or varieties of particular species can be isolated. The conventional ruminant is continuously exposed to airborne anaerobes of the type associated with the main rumen functions (Mann, 1963), and previous work (Hobson et al., 1958) showed continuous variation with time in serological type in populations of bacterial species steady in overall numbers. It may be that re-inoculation with new strains and the presence of a number of strains is essential to the continued function of the bacterial population, some strains degenerating, others taking their place. In the gnotobiotic lambs such replacement is not possible. A similar failure in growth after a period of steady growth was noted in gnotobiotic lambs in earlier experiments (lambs 16a and 18a of Lysons et al., 1977) although in these cases increasing contamination made results difficult to interpret.

\section{Lambs fed on barley/grass or grass alone}

The results show that this feed was being digested and utilized both immediately post-weaning and later (Table 4). The rumen acid concentrations and weight gains in lambs $T$ and $U$ were not as high as in the lambs on the barley diet. This could be a reflection of the lower intake of starch. Overall feed intake, on a lamb weight basis, was similar to that of the previous lambs, but lack of cellulolytic activity suggested that only partial degradation of the grass polysaccharides could be taking place and so the nutritionally valuable carbohydrate intake would be mainly contained in the grain, which comprised about $50 \%$ of the total feed weight. Overall, the lambs grew satisfactorily and the experiment again showed that gnotobiotic lamb rearing on a starchy feed was possible, even if only for a limited period because growth again failed. Interpretation of the final results is complicated by the change in diet, but there is no reason why this should have upset rumen metabolism and it is again suggested that the rumen flora ceased to function adequately, at about the same time as in the lambs on the pelleted barley diet.

A problem in assessing the activities of bacteria in any microbial habitat is that of substrates used in tests. Polymeric substrates isolated from vegetable matter may differ in molecular and macromolecular structure from the polymer in situ in the plant, and may be easily degraded by bacteria which will not attack the native polymer. Or, with the natural association of polymers in the plant structure, bacteria with one depolymerase activity may be needed to expose another polymer to attack. The results with lambs $T$ and $U$ and the experiments of Mann \& Stewart (1974) suggest that this may be the case with the cellulolytic bacteria, which degrade prepared cellulose in vitro but seem to have little, if any, ability to digest fibres in the gnotobiotic rumen. The results also question the relevance of counts of bacteria on prepared cellulose media to fibre-degrading activity in the rumen. Starch, on the other hand, exists as discrete granules which can be isolated from plant tissue without resort to extreme physical or chemical actions; this suggests that starch granules are representative of starch in its native state. A bacterium able to attack these granules should thus be capable of utilizing starch in ruminant feeds, and the rumen fermentations in the gnotobiotic lamb 
suggests that this is so. Fermentation of starchy feeds in the rumen seems to be overall a much simpler reaction than fermentation of fibres, particularly since with the pelleted feeds starch granules are rapidly released into the rumen on disintegration of the pellets (Eadie $e t$ al., 1970). The conventional digestion of starchy feeds can thus be reproduced by a defined rumen flora with only a limited number of types of bacteria. Also, since these bacteria were initially isolated on media containing soluble starch, the results suggest that in this case the use of chemically treated substrate in counting media can give results relevant to starch degradation in the conventional rumen.

We would like to thank Mr G. Cushnie and Mr A. J. Richardson for maintaining the animals and isolators.

\section{REFERENCES}

Alexander, T. J. L., Lysons, R. J., ElliotT, L. M. \& WellsteAD, P. D. (1973a). Equipment for rearing gnotobiotic lambs. Laboratory Animals 7, 195-217.

Alexander, T. J. L., Lysons, R. J., ElliotT, L. M. \& WELlsteAD, P. D. $(1973 b)$. Techniques for rearing gnotobiotic lambs. Laboratory Animals 7, 239-254.

BAKER, F. \& Hobson, P. N. (1952). The selective staining of intact and damaged starch granules by safranin $\mathrm{O}$ and niagara blue 4B. Journal of the Science of Food and Agriculture 3, 608-612.

BarR, M. E. J., ManN, S. O., Richardson, A. J., Stewart, C. S. \& Wallace, R. J. (1980). Establishment of ureolytic streptococci in the rumen of gnotobiotic lambs. Journal of Applied Bacteriology 49, 325-330.

Blackburn, T. H. \& Hobson, P. N. (1962). Further studies on the isolation of proteolytic bacteria from the sheep rumen. Journal of General Microbiology 29, 69-81.

Cheng, K.-J. \& Wallace, R. J. (1979). The mechanism of passage of endogenous urea through the rumen wall and the role of ureolytic bacteria in the urea flux. British Journal of Nutrition 42, 553-557.

Cushinie, G. H., Richardson, A. J., Lawson, W. J. \& Sharman, G. A. M. (1979). Cerebrocortical necrosis in ruminants: effect of thiaminase type 1producing Clostridium sporogenes in lambs. Veterinary Record 105, 480-482.

Cushnie, G. H., Richardson, A. J. \& Sharman, G. A. M. (1981). Procedures and equipment for the rearing of gnotobiotic lambs. Laboratory Animals 15, 199-204.

Eadie, J. M., Hyldgaard-Jensen, J., Mann, S. O. Reid, R. S. \& Whitelaw, F. G. (1970). Observations on the microbiology and biochemistry of the rumen in cattle given different quantities of a pelleted barley ration. British Journal of Nutrition 24, 157-177.

Elliott, L. M., Alexander, T. J. L., Wellstead, P. D. \& LySONS, R. J. (1974). Microbiological monitoring of gnotobiotic lambs. Laboratory Animals 8 , 51-59.

Hamlin, L. J. \& Hungate, R. E. (1956). Culture and physiology of a starch-digesting bacterium (Bacteroides amylophilus, n.sp.) from the bovine rumen. Journal of Bacteriology 72, 548-554.

HENDERSON, C. (1973). The effects of fatty acids on pure cultures of rumen bacteria. Journal of Agricultural Science 81, 107-112.

HENDERSON, C. (1980). The influence of extracellular hydrogen on the metabolism of Bacteroides ruminicola, Anaerovibrio lipolytica and Selenomonas ruminantium. Journal of General Microbiology 119 , 485-491.

Henderson, C., Hobson, P. N. \& Summers, R. (1969). The production of amylase, protease and lipolytic enzymes by two species of anaerobic rumen bacteria. In Continuous Cultivation of Microorganisms, pp. 189-204. Edited by I. Malek et al. Prague: Academia.

Hobson, P. N. \& MacPherson, M. J. (1952). Amylases of Clostridium butyricum and a Streptococcus isolated from the rumen of the sheep. Biochemical Journal 52, 671-679.

Hobson, P. N., ManN, S. O. \& OxFord, A. E. (1958). Some studies on the occurrence and properties of a large Gram-negative coccus from the rumen. Journal of General Microbiology 19, 463-472.

Latham, M. J. \& Wolin, M. J. (1977). Fermentation of cellulose by Ruminococcus flavefaciens in the presence and absence of Methanobacterium ruminantium. Applied and Environmental Microbiology 34, 297-301.

Leat, W. M. F., KemP, P., Lysons, R. J. \& Alexander, T. J. L. (1977). Fatty acid composition of depot fats from gnotobiotic lambs. Journal of Agricultural Science 88, 175-179.

Lysons, R. J., Alexander, T. J. L., Hobson, P. N., ManN, S. O. \& Stewart, C. S. (1971). Establishment of a limited rumen microflora in gnotobiotic lambs. Research in Veterinary Science 2, 486-487.

Lysons, R. J., Alexander, T. J. L., Wellstead, P. D., Hobson, P. N., ManN, S. O. \& Stewart, C. S. (1976). Defined bacterial populations in the rumens of gnotobiotic lambs. Journal of General Microbiology 94, 257-269.

Lysons, R. J., Alexander, T. J. L. \& Wellstead, P. D. (1977). Nutrition and growth of gnotobiotic lambs. Journal of Agricultural Science 88, 597-604.

MaNN, S. O. (1963). Some observations on the airborne dissemination of rumen bacteria. Journal of General Microbiology 33, ix.

MANN, S. O. (1968). An improved method of determining cellulolytic activity in anaerobic bacteria. Journal of Applied Bacteriology 31, 241-244.

MaNN, S. O. \& Ørskov, E. R. (1975). The effect of feeding whole or pelleted barley to lambs on their rumen bacterial populations and $\mathrm{pH}$. Proceedings of the Nutrition Society 34, 63A.

MANN, S. O. \& STEWART, C. S. (1974). Establishment 
of a limited rumen flora in gnotobiotic lambs fed on a roughage diet. Journal of General Microbiology 84, 379-382.

McWethy, S. J. \& Hartman, P. A. (1977). Purification and some properties of an extracellular $a$ amylase from Bacteroides amylophilus. Journal of Bacteriology 129, 1537-1544.

ØRSKov, E. R. (1977). Nitrogen digestion and utilisation in young and lactating ruminants. World Review of Nutrition and Dietetics 26, 225-257.

Ørskov, E. R., Fraser, C. \& KAY, R. N. B. (1969). Dietary factors influencing the digestion of starch in the rumen and large intestine of early-weaned lambs. British Journal of Nutrition 23, 217-226.

Ørskov, E. R., Fraser, C. \& Gill, J. C. (1973). A note on the effect of time of weaning and weight at slaughter on feed utilisation of intensively fed lambs. Animal Production 16, 311-314.
Ørskov, E. R., Fraser, C. \& Gordon, J. G. (1974). Effect of processing of cereals on rumen fermentation, digestibility, rumination time and firmness of subcutaneous fat in lambs. British Journal of Nutrition 32, 59-69.

Scheifinger, C. C. \& Wolin, M. J. (1973). Propionate formation from cellulose and soluble sugars by combined cultures of Bacteroides succinogenes and Selenomonas ruminantium. Applied Microbiology 26, 789-795.

Sharpe, M. E., Latham, M. J. \& Reiter, B. (1977). The immune response of the host animal to bacteria in the rumen and caecum. In Digestion and Metabolism in the Ruminant, pp. 193-204. Edited by I. W. McDonald \& A. C. I. Warner. Armidale, New South Wales, Australia: University of New England Publishing Unit. 